\title{
IGREJA E POVO: CATÓLICOS? OS OLHARES DO PADRE JÚLIO MARIA E DE DOM SEBASTIÃO LEME DA SILVEIRA CINTRA SOBRE A CATOLICIDADE DO BRASILEIRO NA PASSAGEM DO SÉCULO XIX PARA O XX
}

\author{
Church and people: Catholic? The perspective of \\ Father Júlio Maria and Dom Sebastião Leme da \\ Silveira Cintra on the catholicity of Brazil the late \\ nineteenth to the twentieth century
}

Euclides Marchi*

\begin{abstract}
RESUMO
Padre Júlio Maria de Morais Carneiro e Dom Sebastião Leme da Silveira Cintra, em 1898 e 1916, respectivamente, publicaram seus textos nos quais expressavam sua visão de Igreja e dos católicos no final do século XIX e nas primeiras décadas do século XX. Para o olhar clerical, ao iniciar sua trajetória livre da tutela do Estado, a Igreja encontrava-se em condições organizacionais bastante precárias. A instituição estava desestruturada, o clero pouco afeito às suas funções e os católicos sem compromissos com sua religião e com seus ensinamentos. Ao fazer o diagnóstico dos males que afetavam a sociedade e a Igreja, ambos apontavam remédios e soluções para adequar a catolicidade aos parâmetros exigidos pela implantação das reformas romanizadoras adotadas desde a segunda metade do século XIX e pela contundência dos problemas que afetavam as sociedades mundial e brasileira.
\end{abstract}

Palavras-chave: Igreja Católica; clero; povo católico.

\begin{abstract}
Father Júlio Maria de Morais Carneiro and Dom Sebastião Leme da Silveira Cintra in 1898 and 1916, respectively, published their texts in
\end{abstract}

* Professor Sênior dos Cursos de Pós-Graduação em História da UFPR. 
which they express their vision of the Church and of Catholics in the late nineteenth century and early decades of the twentieth century. At the clerical percpective, to start his career free from State, the Church was in very poor organization al conditions. The institution was unstructured, the clergy, little accustomed to their roles and without engagement with the Catholic religion and its teachings. When bouth clergymen diagnosed of the ills affecting society and the Church, they poited out remedies and solutions to suit the catholicity to the parameters required for both the implementation of the Romanized reformation adopted since the second half of the nineteenth century and the preponderance of the problems affecting the Brazilian and world society.

Key-words: Catholic Church; clergy, Catholic people.

Um Estado confessional e uma Igreja estatizada. Juntos por quase quatro séculos de história. Para a historiografia restou uma pergunta: quem teria se beneficiado com esta união? Dependendo do ponto de vista, pode-se responder que ambos, porém, sob uma série de outros aspectos, conclui-se que os dois sofreram prejuízos. Por esta razão, uma análise menos institucional leva à conclusão de que as medidas do governo republicano representaram mais do que uma simples separação. Elas significaram o início da história de uma Igreja livre num Estado livre.

Neste artigo, a percepção dos reflexos dessa união nas condições em que o catolicismo se encontrava após o fim da monarquia brasileira é extraída de dois textos produzidos por autoridades clericais, num período de menos de duas décadas. Em 1898, Padre Júlio Maria de Morais Carneiro publicava uma série de 12 artigos na Gazeta de Notícias do Rio de Janeiro. As publicações foram semanais, de 14 de março a 7 de maio daquele ano** Já em 1916, Dom Sebastião Leme da Silveira Cintra, aos 16 de julho, festa de Nossa Senhora do Carmo, dezoito anos após a publicação de Júlio Maria, por ocasião de sua indicação para o Arcebispado de Olinda, publicava uma Carta Pastoral dirigida ao Ilmo. e Revmo. Cabido Metropolitano, ao Revdo. Clero e aos fieis da Archidiocese de Olinda**. Estes dois documentos trazem informações substanciais para se compreender algumas das situações

** Para este estudo foi utilizada a publicação feita na coleção Cadernos de História da Igreja das Edições Loyola/CEPEHIB de 1983. JÚLIO MARIA, Pe. A Igreja e o povo. São Paulo: Edições Loyola/ CEPEHIB, 1983.

**** Júlio Maria morreria dois anos antes desta publicação. 
vivenciadas, naquele momento, pela Igreja, pelo clero e pelo povo. Cabe destacar que Júlio Maria escreveu seus artigos no final do século XIX, no momento em que a Igreja estava dando os primeiros passos como instituição autônoma. Ainda eram fortes as lamentações por causa da separação e pela perda daquilo que alguns de seus membros consideraram como direitos adquiridos no decorrer dos quatro séculos de união com o Estado. Já Dom Sebastião fala como Arcebispo e escreve sua pastoral quando a Igreja já havia desencadeado um movimento de reorganização interna, com o seu episcopado tendo realizado várias reuniões conjuntas, cujas decisões, encaminhamentos e procedimentos para os fiéis e o clero haviam sido publicados nas pastorais coletivas. Entremeando essas realizações estava um acontecimento que atingira a Igreja de toda a América Latina. Fora realizado, em 1899, o Concílio Plenário Latino-Americano, convocado por Leão XIII, no qual se definiram os procedimentos que deveriam unificar as práticas da catolicidade para esta parte do continente. Também não há como não se perceber que, mesmo após a separação, a Igreja mantinha uma forte presença institucional na sociedade brasileira, especialmente quando se tratava das especificidades regionais, onde o clero e os governantes, embora separados de direito, de fato continuavam atuando em conjunto. Todavia, a questão que se coloca neste artigo foca outro aspecto: qual a situação do catolicismo e das práticas religiosas do povo?

Tanto Júlio Maria quanto Dom Sebastião centraram suas considerações prioritariamente sobre a Igreja e sobre o povo. Seus discursos tornaram-se referência para a análise desses temas, especialmente quando poucos ainda se aventuravam nesta tarefa delicada de fazer diagnósticos e análises que expunham as entranhas da instituição e dos seus membros. Nos olhares de Júlio Maria e Dom Sebastião transparece, de forma incisiva, o afastamento entre a Igreja e seus fiéis e vice-versa. Instituição, clero e fiéis sofriam as consequências dos quatro séculos nos quais a religião católica era uma obrigação social e uma questão de cidadania. E se, naquele período, todos eram obrigados a "ser católico" para ser "cidadão", e se esta fora a condição sine qua non para ser brasileiro com plenos direitos, ninguém precisava fazer esforço para ser católico e para pertencer a Igreja. As duas autoridades clericais deixam claro que a República, ao declarar a separação entre Estado e Igreja, criou as condições para que esta percebesse que, de fato, estava bem mais próxima daquele do que dos seus fiéis. 


\section{O social como preocupação primeira}

Júlio Maria, em 14 de março de 1898, na Gazeta de Notícias do Rio de Janeiro, iniciava a publicação de seus artigos e já no primeiro fazia constar uma afirmação lapidar: "Hoje, sob o ponto de vista social, só há duas forças no mundo: a Igreja e o povo" é o ideal do papa; concorrer para essa união é, em cada país, o dever dos católicos, principalmente o clero. Nós, porém, não poderemos consegui-la nem desviando-nos da rota que a Igreja segue, nem separando-nos do povo"2. E a aproximação da Igreja com o povo passava pelo envolvimento da instituição com a questão social. Seu discurso revela que ele estava motivado pelas ideias de Leão XIII, expressas na encíclica Rerum Novarum de 1891. Dizia ele que o papa lançara a nau da Igreja no oceano agitado das novas ideias e com isso provocara, numa parte do clero, a necessidade de ver o mundo a partir de novos horizontes. Horizontes estes que, até aqui, tinham como limite as "dimensões de uma sacristia, onde não lhe chegam as vozes, que fora tumultuam, das grandes reivindicações populares, mas apenas as vozes dos devotos"3. Além disso, após afirmar o papel do catolicismo nos tempos modernos, terminava o primeiro artigo dizendo: "Os católicos e os padres não podemos aceitá-lo. O nosso dever é mais nobre, mais patriótico, mais cristão: - é fazer nossa a causa social; e, para que a verdade católica triunfe nela, unir, e num só desideratum, as duas grandes forças do mundo: a Igreja e o povo"4.

Dom Sebastião, com sua perspicácia analítica, também começava a sua Pastoral de forma enfática: "Conhecer os males do tempo, estudar as suas causas e preparar os meios de salvação: foi sempre a tactica dos homens da igreja"s. Também ele ancorava seu discurso nas encíclicas dos últimos papas, principalmente as de Leão XIII, considerando-o como o nome que figurava no panteão das glórias mais rútilas do século XIX. Nele buscava

1 JÚlIO MARIA, Pe. A Igreja e o povo. São Paulo: Edições Loyola/CEPEHIB, 1983. p. 35 (artigo publicado originalmente na Gazeta de Notícias do Rio de Janeiro, ano XXIV, 14 de março de 1898, n. 73, p. 1).

2 JÚLIO MARIA, Pe. Ibidem. p. 35.

3 JÚLIO MARIA, Pe. Ibidem, p. 36.

4 JÚLIO MARIA, Pe. Ibidem, p. 37.

5 CINTRA, Dom Sebastião Leme da Silveira. Carta Pastoral. Petrópolis: Vozes, s/d. p. 9. 
as bases de sua argumentação sobre a verdadeira civilização. Inspirava-se, ainda, em Pio X, sobretudo por seu empenho em restaurar todas as coisas em Cristo. O Papa Bento XV, por meio do qual chegara ao arcebispado de Olinda, era lembrado especialmente por seu olhar inquieto sobre o estado moral do mundo, motivado não somente pelos horrores da Primeira Guerra Mundial, mas pelo afastamento dos governos e dos povos das normas da sabedoria cristã ${ }^{6}$. Bento resumia em quatro os males que afetavam a sociedade: "a falta de amor entre os homens, o desprezo da autoridade, a luta injusta entre as diversas classes e a desmedida ambição dos bens da terra" .

E se remover estes males era a grande meta do papa, Dom Sebastião, como Arcebispo de Olinda, também lançara seu olhar sobre os males que atingiam o Brasil naquele momento. Em resumo, o assunto da Pastoral, segundo ele próprio, era verificar quais eram esses males, quais as causas e quais os remédios. Seu programa de trabalho não poderia ser outro senão aquele lançado há vinte séculos por Cristo: a salvação das almas. Desta forma, já no início de suas considerações, mostrava uma sensibilidade para os problemas que atingiam a sociedade, sobretudo nos aspectos sociais, e definia qual deveria ser o papel dos católicos na solução desses problemas.

Numa primeira observação, constata-se que, tanto para Júlio Maria quanto para Dom Sebastião, era preciso "unir a Igreja e o povo". Esse era um indicativo de que os dois estavam separados, isto é, no templo alguns devotos e, na sociedade o povo católico com suas práticas e seus rituais, desinteressado com o que ocorria no interior das igrejas.

Nos textos de Júlio, o movimento social aparecia como a temática que o instigava a escrever e a pregar. No dia 17 de março de 1898, publicava o segundo artigo e na abertura enfatizava: "Os católicos e os padres brasileiros já não devemos ficar fora do movimento social da Igreja"8. Revelava sua preocupação com aqueles que continuavam resistindo às novas forças que agitavam o mundo. Tornava-se contundente ao ressaltar que era preciso

[...] mostrar aos pequenos, aos pobres, aos proletários que eles foram os primeiros chamados pelo Divino Mestre, cuja Igreja

6 CINTRA. Ibidem, p. 10.

7 CINTRA. Ibidem, p. 11.

8 JÚLIO MARIA, Pe. Ibidem. p. 37 (artigo publicado originalmente na Gazeta de Notícias do Rio de Janeiro, ano XXIV, 17 de março de 1898, n. 76, p. 1). 
foi logo, desde o início, a Igreja do povo, na qual os grandes, os poderosos e os ricos também podem entrar, mas se têm entranhas de misericórdia para a pobreza; sujeitar o despotismo do capital às leis da eqüidade; exigir dele não só a caridade, mas a justiça a que tem direito o trabalho; dignificar o trabalhador; cristianizar a oficina; levar no ensino cristão os supremos postulados da consciência humana às fábricas [...]; proclamar bem alto o eminente lugar do operário na cidade de Deus, que Jesus Cristo fundou na terra, não com as castas, as aristocracias, as burguesias ou as dinastias, mas com o povo e para o povo?.

Já Dom Sebastião reiterava que, embora os católicos fossem predominantes a composição da sociedade brasileira e numericamente majoritários, esta maioria não era eficiente, não atuava nem nos destinos sociais da nação e nem nas práticas da religiosidade. Dizia ele "Não somos, os catholicos, uma maioria efficiente nos destinos sociaes da nação"

A falta de convicção e de um comportamento religioso adequado reproduzia-se nos deveres sociais e políticos, dado que não eram católicos os princípios e os organismos da vida política da nação e os depositários da autoridade governamental prescindiam da fé católica. E os católicos, apesar de ser maioria, nada reivindicavam. Assim, dizia ele "Direitos inconcussos nos assistem com relação à sociedade civil e política, de que somos a maioria. Defendê-los, reclamá-los, fazê-los acatados, é dever inalienável"11.

Ao que parece, este discurso reflete que o prelado ainda sofria o desconforto da separação entre a Igreja e o Estado, seguida pela laicização do ensino, das escolas e dos demais organismos da vida pública, das instituições políticas e econômicas, das manifestações literárias, culturais e do corpo legislativo. Enfim, dizia ele, "na engrenagem do Brasil official não vemos uma só manifestação de vida catholica"12.

Mas foi no terceiro artigo que Júlio Maria, aderindo aos posicionamentos sociais da Igreja no final do século XIX, transformou a questão social no tema central das suas reflexões. Voltava a ressaltar que Leão XIII contribuíra para agitar a Igreja e as demais organizações sociais. Os novos

9 JÚLIO MARIA, Pe. Ibidem, p. 37/38.

10 CINTRA. Ibidem, p. 16.

11 CINTRA. Ibidem, p. 17.

12 CINTRA. Ibidem, p. 17. 
posicionamentos papais influenciavam toda a cristandade e repercutiam fortemente nas instituições laicas. Motivado por essas novas ideias, Júlio escrevia: "Precisamos no Brasil, os católicos e os padres, entrar, quanto antes, no movimento social da igreja. Não é só uma necessidade: é nosso dever"13. Ressaltava que a presença da Igreja na questão social não era uma questão de oportunismo, como queriam alguns de seus adversários. Para ele, era uma presença histórica e, para os espíritos esclarecidos e libertos de preconceitos partidários ou teológicos, as agitações dessa época estavam impregnadas do pensamento cristão, embora às vezes desfigurado ou com certos exageros ou diminuições. Em sua análise, fazia uma contundente crítica aos "velhos" sistemas de governos absolutistas, aristocráticos, monopolistas e ressaltava o papel da democracia como "uma nova forma de governo" que agitava o mundo. E, ao referir-se a ela, dizia: "Certos senhores entendem que ela quer e vai expulsar a Igreja do grande banquete social em que todos os direitos, todas as liberdades necessárias, todas as reivindicações legítimas do povo serão proclamadas. Eu, pelo contrário, digo que ela quer brindar ao Cristo" 14 . Ao falar da democracia, dizia que era preciso convidá-la, sem hipocrisia política e nem covardia religiosa, ao banquete do Evangelho. E, após indicar algumas das tarefas que lhe cabiam, destacava que era necessário "transfigurá-la no crisol da Fé".

Àqueles que pensavam que a democracia iria expulsar a Igreja do grande banquete social, fazia-lhes esta pergunta: Expulsar a Igreja, como? A resposta elencava uma série de características da Igreja e concluía com aquela que parecia ser a mais forte dentro dos quadros do seu pensamento: "A igreja é uma obra de Deus no mundo: é a sua obra como Redentor; é mais do que isso: é Ele próprio no templo, nas almas ou na sociedade, isto é, em todo o mundo da redenção" ${ }^{15}$. E, dirigindo-se ao clero e a alguns católicos, ressaltava que, para haver envolvimento da Igreja com o movimento social, bastava sair "um pouco da sacristia; e, unindo-nos ao povo, envolvermo-nos com ele nos raios da verdade"

13 JÚLIO MARIA, Pe. Ibidem p. 39 (artigo publicado originalmente na Gazeta de Notícias do Rio de Janeiro, 20 de março de 1898, n. 79, p.1).

14 JÚLIO MARIA, Pe. Ibidem, p. 40.

15 JÚllO MARIA, Pe. Ibidem, p. 40.

16 JÚlIO MARIA, Pe. Ibidem, p. 41. 
Dom Sebastião também ressaltava a atitude recatada dos católicos do Brasil dizendo que a grande maioria vivia a lamentar e a chorar um passado que se fora, indiferentes à Constituição republicana, ao governo, à imprensa, à literatura, à academia, à indústria e ao comércio, cuja marca maior era o ateísmo. E, a partir deste diagnóstico, concluía que os brasileiros eram católicos de clausura, cuja fé se restringia ao interior das igrejas. Por isso reafirmava: "[...] somos uma maioria asphixiada. O Brasil que aparece, o Brasil-Nação, esse não é nosso. É da minoria".

O prelado reconhecia que esta maioria não era uma força determinante no regime público do Brasil e isso era resultante da falta de compreensão dos deveres sociais, da falta de cultivo de hábitos de propaganda e de tradição de disciplina. Ou seja, faltava uma ação que interessasse à Igreja e à sociedade, isto é, uma ação social católica.

No seu quarto artigo, Júlio Maria retomava a discussão sobre a independência em relação ao Estado e aos poderes constituídos. Parafraseando o Cardeal Manning, da diocese de Londres, ressaltava que o clero deveria buscar a dignidade, a força e a consideração pública e não deveria ser um instrumento do reino nem um apoio ao poder dinástico. Era, sim, uma força social e a Igreja poderia viver muito bem sem a proteção do Estado. Esse era o principal indicativo da liberdade. Por isso, a reconstrução do edifício social deveria começar pelos padres. E, quanto ao Brasil, Júlio observava: "Nós, entretanto, no Brasil, vivemos presos a teias de aranha. Tudo que sai um pouco dos caminhos trilhados nos desgosta e amedronta. Quanto à orientação teológica, não perdemos ainda a catinga do regalismo, do qual, parece, estamos saudosos, como um liberto que suspirasse pelas pancadas do feitor" [grifos no original] ${ }^{17}$. E, quanto ao povo:

Vivemos separados do povo; quase que o povo não nos conhece. Contentamo-nos com uma certa aristocracia de devotos; quase que a nossa aspiração se reduz a vermos os templos bem-enfeitados, um coro bem-ensaiado, e, no meio de luzes e flores, os nossos paramentos bem-reluzentes! Solenidades para os vivos, e pompas fúnebres para os mortos - eis o melhor de nossa atividade. 
Pregação social - não a queremos; o panegírico e o sermão de festa nos bastam para resolver todos os problemas da humanidade! Eis a razão por que não temos nenhum valor social; nem o clero pesa, como devia acontecer, na balança da opinião; nem a Igreja brasileira é ouvida em nenhum dos grandes interesses da pátria ${ }^{18}$.

Dom Sebastião contribuía com esta análise ao enfatizar que os católicos ainda não haviam adquirido a compreensão dos deveres sociais e trazia como exemplo a experiência dos países onde eles constituíam a minoria, porém, a ação social era intensa e se traduzia na organização de universidades, escolas, jornais, representações políticas, cooperativas, ligas operárias, caixas econômicas e toda a sorte de obras que revelavam a força desse grupo. Nesses países, as escolas católicas recebiam subvenções, nada faltava em todos os ramos da vida pública. Lá eles haviam percebido que a solução dos problemas sociais estava no Evangelho e, por intermédio da ação social, faziam valer seus direitos. Isso tudo porque "elles acordaram em tempo do somno tranquillo de uma fé inoperosa, e, das igrejas onde oravam com mystico fervor, saíram para todas as manifestações da vida contemporanea" 19 .

Segundo ele, a forma de agir dos católicos do Brasil permitia que uma minoria decidisse os destinos da religião da maioria da população. E acrescentava: "E nós, nós que somos a maioria, não levamos a desaire o vivermos nivelados, sinão em condições inferiores, com seitas cujos proselytos podem ser numerados, tão poucos elles são" ${ }^{20}$. Se nos países de minoria católica, como nos Estados Unidos, na Inglaterra e na Alemanha, para dar apenas alguns exemplos, a Igreja fruía de regalias, estas mesmas regalias eram negadas à Igreja do Brasil, embora sendo um país de maioria católica.

Júlio Maria, quase no final de suas publicações, ou seja, no décimo primeiro artigo, observava que entre os brasileiros não se demonstrava tanto entusiasmo pela fé católica, não era uma fé de combate e de sacrifício, mas a fé de queixumes, lamentações, da lamúria preguiçosa e estéril. Ele também trazia como exemplo a atitude dos alemães e suas vitórias sucessivas

18 JÚLIO MARIA, Pe. Ibidem, p. 44/45.

19 CINTRA. Ibidem, p. 28.

20 CINTRA. Ibidem, p. 27. 
e estupendas contra os vexames, as exigências e as tentativas do ateísmo filosófico e político, os quais, juntos, queriam anular o catolicismo. Ressaltava que na Alemanha infligiram derrotas a Bismarck e ao despotismo de Estado, conseguiram vitórias no terreno do direito e da liberdade para a Igreja. A Alemanha vivera uma situação semelhante à do Brasil, quando o Josefismo (José II) deixara a Igreja numa situação lamentável, com um clero decadente e com uma fraqueza de espírito religioso. Lá, clero e povo lançaram-se com valor, intrepidez e coragem na luta social, sem lamentar privilégios perdidos, mas reclamando as liberdades e as prerrogativas do direito comum.

Ao espírito de luta do povo alemão contrapunha a inércia e inação dos brasileiros, que esperavam tudo da graça de Deus. Para ele, vivia-se "a lamentar a separação da Igreja do Estado, esquecidos, porém, de que o princípio católico da união tenha sido tão desnaturado e sofismado pelo poder temporal que os próprios católicos não podiam deixar de preferir ao fato de que a Igreja era vítima de um regime de liberdade e de direito comum"21. Que fazer então, perguntava ele: "O que os católicos alemães, como os da América do Norte, fizeram e fazem: do direito comum - nossa arena, da liberdade - a nossa arena, do povo - o nosso aliado"22.

Júlio Maria, ao observar que parte do clero da época via com certa restrição essas propostas de envolvimento com as questões sociais, além de respaldar seu discurso nas ideias do Cardeal Gibbons, Arcebispo de Baltimore, também recorria aos evangelhos e aos atos dos apóstolos, ressaltando que não havia assunto de interesse público que tanto Jesus Cristo quanto os apóstolos não tivessem tratado direta ou indiretamente. A Igreja também, sobretudo com Leão XIII, fazia, constantemente, uma pregação social. Revisitando as Cartas do Apóstolo Paulo, dizia que este discutia com frequência os direitos e os deveres dos cidadãos. E, fundamentando-se em Leão XIII, insistia na necessidade do clero tratar da questão capital dos deveres dos cidadãos. E, com relação ao envolvimento dos sacerdotes com a questão social, retomava Gibbons, para dizer que: "Os assuntos sociais são para o padre, sem dúvida, matéria excepcional; mas, amigo do povo, ele não deve ficar indiferente a nenhuma das questões sociais, políticas ou

21 JÚLIO MARIA, Pe. Ibidem, p. 62 (artigo publicado originalmente na Gazeta de Notícias do Rio de Janeiro, ano XXIV, $1^{\circ}$ de maio de 1898 , n. 121, p. 2).

22 JÚliO MARIA, Pe. Ibidem, p. 62. 
econômicas que dizem respeito ao interesse e à prosperidade da nação; de todas pode e deve tratar, porque o padre é um reformador social" ${ }^{23}$. Mais uma vez ancorado no Cardeal Gibbons, destacava a tese de que tratar desses assuntos era uma maneira de acalmar as agitações populares, era contribuir para a reconciliação dos que estavam encolerizados e isso era bom tanto para o céu como para a terra.

Ao clero brasileiro recomendava e insistia na necessidade de superar os sermões da festa e pregar as questões sociais. Segundo ele, era preciso aproveitar as ferramentas disponíveis, como a imprensa laica e as revistas católicas, para implementar essa pregação. Constatava, todavia, que poucos eram os padres que assinavam essas revistas e, o mais grave, poucos as liam. Fazia ainda referência à Gazeta de Notícias, na qual publicava seus artigos, dizendo que prontamente seu proprietário se dispôs a atendê-lo. Portanto, não faltava espaço para que a Igreja e o clero se fizessem presentes com suas ideias e pregações. Constatava que a razão da inércia era outra: "Temos, repito, muitos padres distintos; temos talentos e virtudes no clero, mas não queremos a peleja. Queremos que o catolicismo triunfe no Brasil; mas sem combatermos! Queremos salvar o povo, mas sem doutriná-lo"24.

Intrigado com tais problemas, Júlio aproveitava as festividades de Domingo de Ramos de 1898 para voltar com força total contra aqueles que resistiam em aplicar suas competências a favor do envolvimento da Igreja e do clero com os problemas que atingiam o povo. Começava por mostrar que Leão XIII fora irredutível ao indicar o caminho para a Igreja e a necessidade de se estar atento aos movimentos que agitavam a sociedade, às revoluções, às aspirações democráticas e às diferentes correntes de pensamento que agitavam o mundo das ideias, bem como as consequências para a Igreja, frutos de certas alianças políticas. E acrescentava que o chefe da Igreja "viu que os reis se tornaram cesarinos e os burgueses, muito cheios de si próprios, nos governos se esqueceram da religião" 25 . Insistia na tese de que o papa apontara, sobretudo, as injustiças contra os operários e as misérias do povo. E aqueles que haviam prometido a liberdade sem religião, governar as nações sem Cristo e a Igreja, nada conseguiram. Vendo todo

23 JÚLIO MARIA, Pe. Ibidem, p. 45.

24 JÚlIO MARIA, Pe. Ibidem, p. 48.

25 JÚLIO MARIA, Pe. Ibidem, p. 50 (artigo publicado originalmente na Gazeta de Notícias do Rio de Janeiro, ano XXIV, 31 de março de 1898, n. 90, p.1). 
este cenário, o pontífice "disse à Igreja, lhe mostrando o povo: mãe, eis teu filho; e disse ao povo, lhe mostrando a Igreja: eis tua mãe!"26.

Júlio respaldava suas ideias em Leão XIII e, desta forma, considerando a Igreja como a mãe que reconhecera a maioridade do filho, opunha-se também àqueles que ainda lutavam pelo retorno à antiga aliança com o Estado e àqueles que queriam imputar à República as causas dos males que atingiam a sociedade. Para ele, essas teses não passavam de heresias, porque a carta de emancipação democrática estava assinada pelo Supremo Pontífice. Destacava, ainda, que o povo já ascendera aos cumes da política e a Igreja era impelida a posicionar-se contra tudo o que violasse os direitos, a justiça e a liberdade. Reafirmando que seria uma heresia querer separar a vida material da espiritual, ressaltava que o reino de Deus não compreendia somente o patrimônio individual das almas humanas, mas também o destino das sociedades políticas.

$\mathrm{E}$, aos que queriam limitar a ação do padre apenas à sacristia ou às coisas espirituais, àqueles que consideravam que a orientação do povo e o auxílio aos governos na direção dos problemas sociais não eram tarefas do padre, dizia ele que essa atitude era uma clara desobediência ao papa e, portanto, era pecado. Para Júlio, tratava-se de ignorância teológica, que levava a dislates como o de confundir democracia com revolução, as aspirações legítimas e cristãs do povo com as exigências insensatas do filosofismo, do racionalismo ou do liberalismo. Na defesa das novas ideias, especialmente no que se refere à liberdade e à democracia, ele insistia: "Nada de receios, pois; não temamos fantasmas; entremos na liberdade, caminhemos para a democracia, confraternizemos com o povo" 27 .

\section{De uma Igreja sem Estado para uma Igreja com o povo}

Para Dom Sebastião, no Brasil os católicos identificavam-se como católicos de nome, de hábito, de tradição e de sentimento. Faltava-lhes a

26 JÚLIO MARIA, Pe. Ibidem, p.50/51.

27 JÚlIO MARIA, Pe. Ibidem, p. 58. 
prática implantada pela Igreja reformada. Ausentavam-se dos deveres sociais e aceitavam, sem reagir, a laicização do país e o expurgo da religião dos organismos públicos. Nada faziam para impedi-lo e pouco realizavam para reconquistar o espaço perdido. Comparando-os com aqueles de países onde eram minoria, dizia: "É que elles, unidos e arregimentados, souberam fazer valler os seus direitos. E nós, os catholicos do Brasil, insulados e dispersos, teimamos em viver chorando um passado que se foi" ${ }^{28}$. Por isso, o Brasil oficial, o Brasil do Estado e da política, já não apresentava nenhuma identidade católica. Por isso o avanço do indiferentismo e do anticatolicismo. Diante do que ocorria na Constituição, no governo, na imprensa, na literatura, nas academias, nas fábricas e no comércio os brasileiros pareciam um povo atheu ou indifferente. Insistia o prelado: "Somos catholicos de clausura; a nossa fé se restringe ao encerro do oratório ou à nave das igrejas. Quando fora da portada dos lugares santos tremulam os nossos pendões, é certo que nelles não fremem enthusiasmos de uma reivindicação jurada; braçadas de flores é que elles levam em suas dobras perfumadas, não são bandeiras de acção, são vexillos de procissão"29.

Dom Sebastião, era enfático ao dizer:

Não agitamos, não movemos, não agimos.

$[\ldots]$

Marasmar, assim, é grave; assim dormir é fatal.

Os resultados ahi estão.

Negá-los é cegueira, seria inépcia dissimulá-los

Tenhamos a sinceridade christã de o confessar: - somos uma maioria que não actua, dizíamos a pouco; agora acrescentamos: somos uma maioria asphixiada

O Brasil que apparece, o Brasil-nação, esse não é nosso. É da minoria.

A nós, catholicos, apenas dão licença de vivermos.

Que humilhação para a nossa fé! ${ }^{30}$

Em sua percepção, a maioria dos católicos não era exemplar na tarefa de observar os deveres estabelecidos pelos mandamentos de Deus e

30 CINTRA. Ibidem, p. 29 
pelas leis da Igreja e vivia afastada dos sacramentos. Eucaristia e penitência eram conhecidas apenas por uma minoria. Era, portanto, uma catolicidade de nome, tradição e hábitos, mais afeita a beijar a cruz e a Virgem do que à frequência aos sacramentos ou à observância daquelas práticas que a Igreja caracterizava como as que, efetivamente, salvavam as almas. Destas, eles haviam se afastado desde a mocidade.

Também Júlio Maria, por ocasião da publicação do seu primeiro artigo, fazia uma advertência, dizendo que: “[...] não nos é lícito, enfim, encastelarmo-nos nos santuários e, contemplando de longe o povo, pensar que fazemos a obra de Deus só com nossas devoções, as nossas festas e os nossos panegíricos" ${ }^{\prime 3}$. Suas considerações estão marcadas por uma crítica a uma tipologia de fé e de teologia que se restringia às antífonas e aos ritos, a uma piedade que não percebia a gravidade da questão social.

Gravidade essa que poderia ser melhor percebida a partir da nova condição de liberdade da Igreja, podendo se aproximar do povo sem as amarras de uma política monárquica, patrocinada por um Estado confessional. Júlio, fazendo coro com vários outros discursos publicados por bispos e leigos, mostrava a importância da separação como fator de liberdade para ambos e como excelente oportunidade da Igreja se aproximar do povo.

Para respaldar suas teses, na publicação do seu quarto artigo, dialogava com algumas autoridades eclesiásticas como o Cardeal Manning, cujo lema era: "É preciso unir a Igreja e o povo" 32 . Como fundamento, selecionara um texto dele que dizia: "A autoridade passou das classes às massas; o futuro é da democracia; uma missão nova é imposta ao clero; a Igreja não tem mais que tratar com os parlamentares e os príncipes, mas com o povo; essa é a nossa obra; para cumpri-la, precisamos de um espírito novo"33.

Júlio ressaltava que aquele era o momento mais oportuno para a Igreja unir-se ao povo. O estado social do Brasil estava numa decadência profunda, o desânimo, as angústias da sociedade o pediam e esperavam por um remédio divino. E, segundo ele, o que fazia a Igreja? Permanecia quieta. Afirmava então: "Ouve-se o murmúrio dos ritos no templo; ouve-se o entoar das antífonas no santuário; mas a palavra social do catolicismo,

31 JÚLIO MARIA, Pe. Ibidem, p. 36.

32 JÚLIO MARIA, Pe. Ibidem, p. 42 (artigo publicado originalmente na Gazeta de Notícias do Rio de Janeiro, ano XXIV, 24 de março de 1898, n. 83, p.1).

33 JÚLIO MARIA, Pe. Ibidem, p. 42/43. 
o brado nacional da fé, a doutrinação popular e patriótica do Brasil, onde estão?! Esposando os sentimentos de políticos interessados, certo número de católicos e padres abre a boca, mas só em particular e para dizer: o mal é a República" [grifos no original] ${ }^{34}$.

E, rebatendo esta tese, ressaltava que a República tinha apenas oito anos e que, neste prazo, não se teria conseguido formar sequer um menino, quanto mais um povo. Ela tinha, sim, seus erros, mas as ideias liberais contra o catolicismo, as leis anticristãs, a política racionalista e pagã tinham mais de meio século. $\mathrm{O}$ trono ofendera a Igreja condenando bispos ao trabalho forçado, o anticlericalismo era explícito, nenhum estadista monárquico cogitara o catolicismo como elemento político e social. Portanto, imputar à República a responsabilidade pelos males sociais não passava de um sofisma. E complementava sua tese dizendo: "O trono caiu; a República precisa tirar proveito da lição divina; mas a nós é que cabe ensinar-lhe; e nós ensinaremos à República não mostrando-nos apegados a formas de governo, mas cheios de fé, de patriotismo e de amor à liberdade" 35 . Júlio, aproveitando a data de Domingo de Ramos, concluía seu sétimo artigo de forma apoteótica: "As hosanas do povo, como os gritos vitoriosos de Jerusalém, misturar-se-ão com os sons harmoniosos da alegria sagrada. Povo e clero, num só saltério, poderão celebrar, na mesma festa grandiosa e expansiva - a entrada triunfal de Cristo no Brasil" ${ }^{\prime 36}$.

Dom Sebastião, embora não se referindo especificamente aos males da República, buscava entender a situação religiosa do Brasil que, para ele, era muito específica e diferente de outros países como os da Europa. Lá as diferenças entre os credos eram nítidas: de um lado os católicos, de outro os acatólicos. Já no Brasil não era bem assim, pois a diferença de credos não se mostrava tão antagônica e não ferviam ódios de religião, pois quase todos se declaravam católicos. E, segundo ele, pelo fato de quase todos pertencerem à mesma religião, não era sequer possível auferir o esplendor dessa situação. A partir desta observação, Dom Sebastião afirmava: "Somos um paiz, na sua grande maioria, catholico" ${ }^{37}$ e indicava que a catolicidade poderia ser observada no nome das cidades, das aldeias, dos povoados, no

37 CINTRA. Ibidem, p. 14. 
tamanho das igrejas, nas romarias e devoções. Segundo ele, o catolicismo não era apenas uma religião impregnada de tradições, mas a elas se entrelaçavam variadas manifestações de uma fé intensa e profunda.

Todavia, do ponto de vista de seu olhar episcopal, a maioria absoluta da nação não vivenciava o catolicismo. Deixava claro que, ao não obedecer a Deus e à Igreja, caracterizava-se uma descrença generalizada. Nesse sentido, o Arcebispo não tergiversava: ou se era ou não se era católico. Afirmava, convictamente, que o que existia era uma maioria ineficiente. Constituía uma grande força, mas que não atuava, não influía e era uma força inerte. Se realmente tivesse fé, deveria propagá-la. Tal indiferença era uma traição à pátria e a Jesus Cristo. Por isso, era preciso romper o marasmo e deixar de ser maioria nominal, esquecida de seus deveres e sem consciência dos direitos. Se este era o grande mal, buscar a cura seria um ato de fé e patriotismo.

Como causas da ineficiência e da falta de atuação, o prelado destacava a fome de prazeres, as paixões, os instintos, os egoísmos, as volúpias, a sensualidade, a sede de riquezas, a falta de honestidade, o assalto aos poderes públicos, a tolerância da opinião pública em determinadas situações e o seu despotismo em outras, facilitando o abandono das coisas do espírito e a aproximação com os bens materiais e com os males da carne. Tudo isso concorria para o afastamento das práticas do cristianismo e para o descumprimento das obrigações sociais e religiosas. Dizia ele: "É evidente, pois, que apesar de sermos a maioria absoluta do Brasil, como nação, não temos e não vivemos a vida catholica" ${ }^{38}$. E o arcebispo era categórico ao afirmar que se os católicos não acreditavam em Deus e na Igreja não deviam esconder essa descrença: "Digamo-lo francamente: não somos catholicos" 39 . Para ele, a pátria precisava da influência social dos católicos: "Ella tem o direito indiscutível a exigir de nós uma floração de virtudes privadas e cívicas que, estimulando a todos no cumprimento do dever, em todos se infiltrem para gérmen da probidade e são patriotismo" "Incitava-os a que tornassem conhecido o reinado de Cristo, para que Ele vivesse, reinasse, imperasse e dominasse nos indivíduos, na família e na sociedade. E acrescentava "Eis por que, com todas as energias de nossa alma de catholicos e brasileiros,

39 CINTRA. Ibidem, p. 19.

40 CINTRA. Ibidem, p. 19. 
urge rompamos com o marasmo atrophiante com que nos habituamos a ser uma maioria nominal esquecida dos seus deveres, sem consciência dos seus direitos" [grifos no original] ${ }^{41}$.

Na sua Carta Pastoral, Dom Sebastião apontava os males, dizendo que: o respeito humano e a fome de prazeres eram instintos e paixões perversas que levavam o homem a abandonar as práticas religiosas. As consequências disso eram a desonestidade, a ambição, a vontade de acumular dinheiro, aproveitando-se dos poderes públicos em benefício próprio, sob os olhares tolerantes da opinião pública.

Insistia, no entanto, que os males não estavam na forma de governo, na República ou em outros regimes. Estavam, sim, na ignorância religiosa, considerada por ele como a causa última dos nossos males. Júlio Maria também destacava que a forma de governo e os diferentes regimes políticos não eram responsáveis pelos males que atingiam a sociedade. Referia-se à conduta que católicos e padres deveriam ter em relação ao regime republicano, destacando que "combater os seus erros - é o nosso direito; harmonizá-lo com todos os interesses da religião - é o nosso dever"42. Opunha-se a qualquer movimento que trabalhasse para que a República viesse a cair e se instalasse qualquer outra forma de governo. Para ele, essa era uma "sugestão diabólica". A sorte da Igreja não deveria se atrelar a nenhum regime político e os católicos e os padres não poderiam ter tanta certeza de que, se outro regime viesse a se instalar, sua permanência seria duradoura. Referindo-se aos católicos e aos padres do Brasil, ressaltava: "Podemos e devemos combater todos os erros da República, em matéria de religião; não podemos, porém, negar, direta ou indiretamente, ao regime democrático e à causa pública o nosso esforço, o nosso trabalho, a nossa sincera e leal cooperação"43.

Dom Sebastião, retomando as encíclicas papais, em especial as de Pio $\mathrm{X}$, reconhecia que o mundo vivia numa época de ciência e luz, progresso científico e tecnológico, produção industrial, bibliotecas, laboratórios, enfim, toda a sorte de avanços e transformações. Todavia, lamentava que os conhecimentos religiosos não avançassem na mesma proporção. Tudo

41 CINTRA. Ibidem, p. 20.

42 JÚLIO MARIA, Pe. Ibidem, p. 54 (artigo publicado originalmente na Gazeta de Notícias do Rio de Janeiro, ano XXIV, 17 de abril de 1898, n. 107, p. 2).

43 JÚLIO MARIA, Pe. Ibidem, p. 55. 
era estudado, menos a religião. Para ele, a mais funesta das ignorâncias era a religiosa. Por isso, paralelamente ao progresso da ciência, crescia o menosprezo pela religião em decorrência da total falta de conhecimento. Dizia ele: "Entre os homens cultos, como entre os homens do povo, em todas as camadas sociaes, geralmente falando a religião ou é mal conhecida ou é de todo ignorada" [grifos no original] ${ }^{44}$.

Ao aprofundar-se na análise do tema da ignorância religiosa, buscou caracterizá-la tanto no meio intelectual quanto entre o povo. Quanto aos intelectuais, classificou-os em várias categorias: literatos de sentimentos cristãos, dentre os quais alguns tinham certa admiração pela religião, “[...] Mas elles desconhecem os nossos dogmas, não estudam a nossa história, menosprezam a nossa liturgia" ${ }^{45}$. Apenas viram a fé de longe. Possuíam certo sentimentalismo e a instrução religiosa poderia servir-lhes de fonte de inspiração. Mas, como isso não ocorria, cometiam erros, divulgavam inverdades e revelavam muita ignorância. Literatos anticristãos, discípulos de Voltaire, Zola e Renan que não respeitavam a Igreja e, ao combatê-la, não eram leais, porque deformavam as crenças, desvirtuavam os dogmas, truncavam o evangelho, falseavam a história. Nem sempre o faziam de má fé, mas, sobretudo, por ignorância religiosa. Outra categoria era a dos intelectuais indiferentes. Nela não incluía apenas os literatos, mas todos os homens cultos, os intelectuais de todos os gêneros. Dizia ele: "Estudam, é verdade, mas em seus estudos prescindem da religião, abstraem a sua moral, não cogitam da sua elevação e belleza" ${ }^{\text {46 }}$. Eram homens de estudo, que se dedicavam aos mais diversos campos do saber, mas que não estudavam a religião e nem as disciplinas que a ela se prendiam. Eram filósofos, sociólogos, juristas, historiadores, políticos e estadistas, homens que não se preocupavam com as questões da religião e não a conheciam. Somavam-se a eles os intelectuais incrédulos, que não desconheciam tanto as doutrinas que atacavam como os argumentos da religião. Segundo o prelado, eram inimigos perversos e gratuitos. Ressuscitavam questões já respondidas e explicadas. Eram arcaicos e se agarravam fanaticamente a certos ídolos e a certas palavras, acreditando que elas traduziam o pensamento moderno.

$\begin{array}{ll}44 & \text { CINTRA. Ibidem, p. } 32 . \\ 45 & \text { CINTRA. Ibidem, p. } 35 . \\ 46 & \text { CINTRA. Ibidem, p. } 37 .\end{array}$ 
Havia, ainda, a idolatria da ciência, como se ela pudesse explicar tudo e como se todos os problemas e enigmas pudessem ser resolvidos por ela. Grandes sábios como Pasteur derrubaram o mito da ciência onipotente, a ciência como uma religião. A ciência inimiga da religião não cumpriu a promessa de tudo explicar. Lamentava que certos pensadores brasileiros tivessem ficado atrasados no movimento intelectual mundial, especialmente por ignorarem tudo o que concernia à religião.

$\mathrm{Na}$ carta, não faltou uma crítica aos positivistas, dizendo que a notícia de que no Brasil existia uma escola positivista causava certo pasmo aos europeus. Na França, faziam-se ironias sobre as contribuições dos generosos positivistas brasileiros para a construção do templo da Rua Paienne, 5, em Paris. Destacava ele que o nosso país era a Galileia dos apóstolos do positivismo. Todavia, embora homens de valor intelectual e moral, nossos poucos positivistas ortodoxos sofriam das consequências do agnosticismo e do mesmo mal dos demais: a ignorância religiosa.

Finalmente, referia-se aos intelectuais católicos que se sobressaíam no mundo das letras e da ciência. "São intelligencias cultas, eruditos professores, apreciados literatos, homens de sciencia, escriptores de nomeada e publicistas de nota"47. Havia na capital do país uma plêiade de intelectuais que eram baluartes da Igreja. Afora esse grupo seleto que vivia na capital, aos demais, embora muito bons, com raras exceções, faltava-lhes a instrução religiosa. Por isso, não conseguiam enfrentar as investidas contra a religião feitas pelos incrédulos e se tornavam apáticos na defesa dos princípios da fé católica.

\section{A Igreja e o clero em busca do povo}

Se a nova situação da Igreja separada do Estado, se a perda de privilégios e as vantagens de uma Igreja livre, se a questão social recebeu as atenções de Júlio Maria, ao que tudo indica esse não era seu problema principal. Para ele, o que merecia maior atenção dos padres e dos católicos 
naquele momento de transição era a união do povo com a Igreja. Dizia: “A união do povo e da Igreja - que campo tão vasto para a atividade dos padres e dos católicos! Que missão gloriosa para o clero contemporâneo! Que excelente e providencial recurso para o clero brasileiro!" e imediatamente perguntava-se "Esse recurso não compensa excessivamente os privilégios perdidos?! Não é mais bela para o clero a aliança do povo que a proteção dos governos?!"48

Para Júlio, as benesses do Estado não fariam falta se a Igreja se unisse ao povo. Mas qual a relação que se deveria estabelecer e o que faria esse povo? E, para dirimir possíveis dúvidas, dizia ele:

\begin{abstract}
Não; o povo não será sacristão, nem fabriqueiro, nem teólogo. Não terá, sem dúvida, capacidade bastante para prestar ao clero tão preciosos serviços. O povo, porém, será o grande e devotado auxiliar da Igreja. O clero conhecerá melhor por isso mesmo as idéias, os sentimentos e os desejos do povo. Clero e povo identificados - nem o clero morrerá de fome, na falta de um mesquinho salário oficial, dado em permuta de tanta exigência e tanta sujeição; nem o povo morrerá à míngua de verdade, porque lhe falte o contato, a convivência com aqueles que devem ser os seus mestres e conselheiros. Como já acontece, não veremos, é verdade, as pomposas e convencionadas saudações, em dias de gala [grifo no original], do cetro e do báculo; mas na grande gala da liberdade, como nos dias do Divino Mestre, nós veremos abraçados a Igreja e o povo ${ }^{49}$.
\end{abstract}

Seu texto era forte, sua análise atingia diretamente as atividades do clero e da igreja. Parece que ele mesmo percebeu a contundência de suas críticas aos colegas de sacerdócio. Para suavizá-las, dá uma demonstração de otimismo e de proatividade dizendo: "Mas nós temos talentos e virtudes no clero; precisamos reagir. Com descontentamento embora dos emperrados, precisamos começar a grande cruzada: dar a religião à pátria, a Igreja ao povo" ${ }^{50}$. Embora otimista e proativo, a publicação do seu quinto artigo reacendia a tese das funções do clero. Mais uma vez, para não mostrar

48 JÚLIO MARIA, Pe. Ibidem, p. 38.

49 JÚLIO MARIA, Pe. Ibidem, p. 39.

50 JÚLIO MARIA, Pe. Ibidem, p. 45. 
que estava sozinho nesta batalha, dialogava com o cardeal Gibbons. Dele selecionou o texto que aparecia no livro do Monsenhor Ireland, A Igreja e século, no qual se lia: "O papel do clero hoje não pode consistir em celebrar a missa, administrar os sacramentos e acompanhar procissões. O seu dever é unir-se ao povo, identificar-se com ele, para que o clero e o povo deixem de caminhar ao lado um de outro como duas correntes, uma de óleo outra de água, que nunca se encontram" ${ }^{51}$.

Dom Sebastião, em sua Pastoral, também destinou grande parte do texto ao povo católico, sobretudo no que dizia respeito à ignorância religiosa. $\mathrm{O}$ povo foi descrito assim pelo prelado:

O povo! Essa grande massa que, nas energias inconsumíveis da sua tempera, constitue o nervo resistente à dissolução da pátria; esse povo imenso que forma aquillo que o Brasil tem de mais puro e forte, esse heróico povo brasileiro, cuja fibra soffredora tem sido uma verdadeira odysseia da luta insana contra os elementos da natureza e as injustiças dos homens; esse povo desconhecido que jornadeia na vastidão dos campos ou lida no vai-vem das cidades; o povo, enfim, o povo rude e pobre, é victima da mais lamentável ignorância religiosa ${ }^{52}$.

Ainda segundo ele, era um povo que se alguém tentasse contra a existência dos nossos altares, explodiria em reação temível. Por isso, dizia: "A nossa gente não compreende o atheu, tem horror ao ímpio, detesta o herege" $" 53$. Baluarte da religião, movido por profundo sentimento de religiosidade, nela buscava arrimo, alento e força para suportar os difíceis momentos da vida. Todavia, este mesmo povo era susceptível aos encantos e às crendices, especialmente as do espiritismo, que se enraizava com muita facilidade no seu imaginário e explorava a religiosidade popular. Sem instrução religiosa, se tornava ávido por formas diferentes de culto. E, na defesa deste povo, Dom Sebastião atacava com veemência os fenômenos dos espíritos falantes e das superstições. $\mathrm{O}$ veneno estava nas explicações sobre o aparecimento dos espíritos e no fanatismo religioso. Ao esmerar-se

51 JÚLIO MARIA, Pe. Ibidem, p. 45 (artigo publicado originalmente na Gazeta de Notícias do Rio de Janeiro, ano XXIV, 27 de março de 1898, n. 86, p. 1).

52 CINTRA. Ibidem, p. 54.

53 CINTRA. Ibidem, p. 55 
em demonstrar a falsidade e a insensatez dessa crença, insistia que uma das tarefas do padre era a de instruir o povo para que a elas não prestasse fé.

Antes mesmo de Dom Sebastião, Júlio Maria também voltara suas atenções para o que ele entendia ser uma das tarefas do padre. Ensinava ele: "O padre deve amar o povo, deve procurar o povo, deve defender o povo, deve unir a Igreja e o povo" 54 . E, referindo-se à ignorância, destacava que o padre não deveria odiar a ciência, o progresso e a liberdade, pois não tinha sido a ciência quem censurou a doutrina do Mestre: fora a ignorância. Não fora o progresso quem condenou o Mestre, mas a rotina. Não fora a liberdade quem executou o Mestre, mas o despotismo. E, se Cristo era Luz, o padre não tinha o direito de ser obscurantista. Cristo era renovação: o padre não tinha o direito de ser retardatário. Cristo era a liberdade que preferiu o opróbrio, a ignomínia e a morte à escravidão do poder político. Por isso, o padre não tinha o direito de ser a favor dos regimes absolutistas e contra os regimes liberais. Todavia, dizia, se justamente:

[...] quando a verdade do Cristo brilha mais ampla nos horizontes da igreja; quando ela nos mostra na fronte do papado nova e tríplice manifestação da ciência, progresso e da liberdade; quando o espírito humano, encantado diante de Leão XIII, reclama os divinos legados, e o povo exige que se cumpra o testamento cristão, o padre fugir da ciência, desconfiar do progresso, detestar a liberdade, repelir o espírito humano, distanciar-se do povo e esconder-se nas sacristias, que poderá ser o padre? ${ }^{55}$

Ponderava ainda que a imagem de padre como mero administrador de sacramentos já era repelida na maioria dos países, inclusive por muitos padres no Brasil. A seu modo de ver, já se podia notar a presença de um espírito apostólico onde se combinavam os interesses da terra com os valores do céu, a dignidade da razão humana com a divina autoridade da fé, as belezas da ciência com as harmonias da revelação, o culto cristão com o culto da pátria e o amor de Deus com o amor do povo.

Por estas e outras razões, Dom Sebastião não vacilava em apontar como a principal tarefa do sacerdote a pregação dominical. A esta acres-

54 JÚLIO MARIA, Pe. Ibidem, p. 59.

55 JÚLIO MARIA, Pe. Ibidem, p. 60. 
centava outra: leitura, que deveria ocorrer em todas as ocasiões, no lar, na escola e no catecismo. A eficácia da pregação ficava bastante comprometida porque não se tinha um método ou um plano. As prédicas eram geralmente avulsas, sem lógica e sequência. Muitas vezes eram exortações, sem nenhum ensinamento, que atingiam as mesmas pessoas, aquelas que menos necessitavam. Os que mais precisavam, de modo especial os homens, geralmente não as ouviam.

Para garantir bons resultados à pregação, duas condições eram fundamentais: a propaganda e a pontualidade. Os anúncios prévios, a divulgação na imprensa e entre os amigos e a observância rigorosa dos horários preestabelecidos eram condições fundamentais. Nas cidades, para se atingir aqueles que trabalhavam, dever-se-ia pregar à noite. No campo, era preciso realizar as missões de forma mais constante e metódica.

Dom Sebastião fez uma referência especial ao hábito da leitura como um precioso veículo de instrução religiosa. Era fundamental valer-se da imprensa, dos boletins paroquiais e dos impressos doutrinários. Esses veículos aumentariam o número de ouvintes-leitores e garantiriam a divulgação da boa leitura. Havia uma verdadeira "fome" de leitura e impedi-la seria insensato. Recomendava a divulgação de obras ou manuais já conhecidos ao invés de livros de devoção, sobretudo aqueles cheios de ideias inexatas ou editados sem nenhum critério.

Se nas duas primeiras partes de sua pastoral o prelado ateve-se mais ao diagnóstico ou à análise do catolicismo no Brasil nas primeiras décadas do século XX, na terceira parte ele apontava os remédios. E, falando como pastor, dirigindo-se ao clero e aos fiéis, assumindo uma postura mais incisiva e, até certo ponto, ordenativa, dizia: "Diagnosticado o mal, estudada que foi a sua etiologia, é, agora, a vez da therapeutica e prophylaxia". E: "Qual é, pois, o supremo remédio para sanar e prevenir o grande mal da ignorancia religiosa"? Ele mesmo respondeu: "inquiri-lo é o mesmo que responder. $A$ instrução religiosa: eis a grande salvação" [grifos no original] ${ }^{56}$.

Sabia ele que o povo brasileiro era muito sensível às coisas da religião, mas reiterava que sentimento não era conhecimento. Por isso, dizia: "Não nos engane a profunda religiosidade do povo. Bem sabemos que ninguém jamais conseguirá extinguir nelle o sentimento religioso. Mas 
sentir não é conhecer. $\mathrm{O}$ homem não é apenas animal que sente; acima da vida sensitiva, temos a vida racional e intellectiva" ${ }^{57}$. Tornava-se mais explícito ao afirmar que o povo não possuía as menores informações sobre a doutrina cristã, sobre a pessoa humana e sobre a obra de Jesus Cristo. Tinha, mal e mal, uma vaga ideia da autoridade divina da Igreja e, também, da instituição divina dos sacramentos. Lembrando Aristóteles, ressaltava: "Nihil volitum, quin praecognitum" 58 .

Valendo-se de um texto de Dom Duarte Leopoldo e Silva, Arcebispo da Diocese de São Paulo, publicado no Anuário da Archidiocese nos anos de 1912-1913, destacava que, se o povo conhecesse a religião, certamente cederia à evidência dos fatos e a praticaria. Por esta razão, sem o ensino da religião por meio da palavra oficial da igreja, intérprete autorizada da palavra divina, ministrado em larga escala, "que havemos de esperar de catholicos de occasião ou de poesia, sinão vergonhosas e tristes defecções, hábitos e processos absolutamente contrarios à Lei de Deus?" 59 . E Dom Duarte, no texto inserido na Pastoral de Dom Sebastião, perguntava:

São catholicas essas respeitáveis senhoras, que solicitam a graça dos sacramentos descurando deveres imperiosos de estado ou de família? Donde vem essa fraqueza de caracter a que succumbem, na vida practica, tantos mocinhos, ainda hontem collegiaes modelos e esperançosos? Por que a esposa de hoje não é mais a moça piedosas que hontem foi? Donde enfim, tanto mal e tanto escândalo, senão da ignorancia religiosa ou do conhecimento incompleto do dever christão? [grifos no original] ${ }^{60}$

E acrescentava que, por causa da ignorância, grande parte dos católicos era simplesmente crédula, mas, na verdade, não tinha fé. A credulidade subsistia ao sabor das fantasias, da superstição e do erro, aceitava tudo sem nada examinar. Para o Arcebispo, a fé era racional, nada aceitaria sem motivos sérios, tanto de ordem intelectual quanto moral. Estabelecendo diferenças entre o homem crédulo e o homem de fé, dizia: o primeiro crê

57 CINTRA. Ibidem, p. 69.

58 CINTRA. Ibidem, p. 23.

59 CINTRA. Ibidem, p. 25.

60 CINTRA. Ibidem, p. $25 / 26$. 
em si mesmo, enquanto o segundo crê em Deus. Até mesmo para muitos daqueles que frequentavam os sacramentos faltava-lhes saber que precisavam de verdades sólidas e não de fantasias injustificadas. Lágrimas, emoções, arrebatamentos, êxtases, devoções complicadas não eram sinais evidentes da presença de Deus. A fé sólida, racional se manifestava, sobretudo, pela aceitação sobrenatural, voluntária e generosa do dever cotidiano.

Dom Sebastião não desprezava as manifestações e rituais que representavam a exteriorização da fé, muitas delas com requintes de suntuosidade e esplendor. Elas caracterizavam uma tendência natural das camadas populares para as encenações vistosas e refletiam a profundidade de um sentimento de religiosidade, traduzida em atos e procedimentos, festas populares, procissões, batismos, que, além de respeitar os símbolos e os sufrágios da religião, serviam para identificar o cidadão católico. As romarias aos santuários, a suntuosidade das procissões, o respeito, a devoção, o acatamento aos préstitos religiosos causavam emoção e revelavam que o povo brasileiro era católico. Isso para ele não era mera tendência das camadas populares, era de fato a religiosidade que predominava e que se refletia no respeito pelos espaços sagrados, pelos templos, pelo batismo das crianças, pela aceitação dos sacramentos e que mostrava que o povo brasileiro professava a religião católica. Por isso ele reiterava: "Somos um paiz essencialmente catholico"61.

Aos sete de maio de 1898, Júlio Maria publicava o último dos doze artigos na Gazeta de Notícias. Abria o texto insistindo na aliança entre a Igreja e o povo, consideradas por ele como as duas forças do mundo ${ }^{62}$. Portanto, não era lícito fazer do catolicismo um retiro para os que, repudiando a solidariedade humana, não queriam as responsabilidades do seu tempo e os labores de sua geração. Os templos não poderiam mais ser os refúgios da fé, satisfeita com as decisões do místico repouso, mas indiferente a todas as necessidades da pátria e do povo. Não se tratava, segundo ele, de deixar de lado o princípio fundamental do apostolado católico, que era a renovação interior das almas, o desenvolvimento das virtudes interiores que operavam o Reino de Deus no aspecto pessoal e íntimo. Segundo ele: "É opinião

61 CINTRA. Ibidem, p. 16.

62 JÚLIO MARIA, Pe. Ibidem, p. 62 (artigo publicado originalmente na Gazeta de Noticias do Rio de Janeiro, ano XXIV, 7 de maio de 1898, n. 127, p. 2). 
absurda e herética a que reduz o apostolado católico só ao ministério espiritual. O cristianismo tem uma virtude política da qual depende toda e qualquer sociedade, como o corpo depende da alma. Não somente as almas, também as nações precisam do cristianismo. Não há somente misérias, sofrimentos, dores individuais; há igualmente fraquezas, males, doenças nacionais" ${ }^{\prime 3}$.

E na busca de uma síntese das suas ideias detalhadas nos doze artigos, dizia: "A Ciência quer a nossa síntese. Já não nos basta o panegírico. $\mathrm{O}$ século quer as nossas fórmulas; já não bastam antífonas. O povo quer a nossa justiça; já não basta ensinar paciência e resignação. Tudo reclama o Cristo; não podemos escondê-lo nos templos" [grifos no original] ${ }^{64}$.

Foi contundente ao afirmar que era preciso entrar no combate e dizer aos sábios que "somos ciência", ao século que "somos progresso", ao povo que "somos amor". Os sábios, o século e o povo ouviriam a Igreja se percebessem que ela era sábia, que se renovava incessantemente e que não estava amarrada a regimes e a partidos do passado, mas que queria uma participação na causa pública e que ela era sensível a todos os males. Que, "como Cristo, fazemos nossa a causa dos pequenos, dos fracos, dos pobres, isto é, da maioria do gênero humano"65.

E se Júlio Maria falava de sábios, da ciência, do século, dezoito anos depois, Dom Sebastião, insistindo na importância da instrução religiosa para se conseguir chegar a esse povo, defendia a instrução religiosa a partir do lar. As ideias recebidas no colo materno eram aquelas que mais durariam, por isso, não bastava a instrução religiosa administrada na escola ${ }^{*}$. A instrução a partir do lar era a principal responsável pela formação do espírito e do caráter.

Aos pais caberia ensinar os conhecimentos celestes, os deveres da vida cristã, infundir ódio aos vícios e amor às virtudes e, finalmente, deveriam dar o bom exemplo. Baseada na fé e na moral católica, a obrigação de educar os filhos era imposta por lei natural e divina, da qual os pais não poderiam se eximir. Uma boa educação austera e cristã era o melhor dos tesouros que os pais deixariam para seus filhos. Como princípio central,

63 JÚLIO MARIA, Pe. Ibidem, p. 63.

64 JÚLIO MARIA, Pe. Ibidem, p. 65.

65 JÚLIO MARIA, Pe. Ibidem, p. 65.

Cabe lembrar que no momento em que escrevia a sua Carta Pastoral a escola era leiga e nela já não ocorria a instrução religiosa. 
afirmava que "a sociedade de amanhã, os seus homens e suas famílias, os seus princípios e os seus costumes, estava tudo nas mãos dos pais". Ao clero restava a obrigação de seguir o que mandava a Pastoral Coletiva dos Bispos (referia-se à Pastoral de 1915), ensinando que somente na Igreja de Jesus Cristo se encontravam as regras seguras para a boa educação dos filhos.

Retomava o valor da escola como fonte de instrução religiosa. Para ele, o ensino religioso era indispensável. O episcopado e o clero não poderiam se omitir sobre os destinos dados à escola porque isso seria trair a missão de pastores. Resgatando vários autores que discorreram sobre o tema, ressaltava que, se a escola moderna era o templo da ciência, não poderia deixar de lado o ensinamento da mais importante delas - a religião. Defendia a tese de que os pais tinham direitos e deveres sobre a educação dos filhos e sobre a escola. Por isso, o Estado não poderia impor um ensino leigo contra a vontade dos pais, nem poderia chamar a si a educação do futuro cidadão. Impor ensino leigo aos filhos de pais católicos seria uma tirânica usurpação e uma clamorosa injustiça, porque obrigava os pais a pagar impostos para uma finalidade que eles detestavam. Não cabiam os argumentos de que o Estado estaria defendendo a liberdade espiritual da criança, porque a única influência que poderia ser exercida sobre o espírito infantil era a influência paterna. Por isso, o ensino leigo era um absurdo. E os pais? Era pecado grave matricular seus filhos em colégios anticatólicos nos locais onde funcionavam escolas católicas.

Frente a isso, qual seria o dever dos sacerdotes e dos católicos? Mostrar que o mundo contemporâneo era contra a oficialização do ensino, desencadear intensa propaganda em favor da escola e do ensino da religião. Divulgar que as reformas do ensino eram uma humilhação do patriotismo, reclamar o ensino religioso facultativo e escolas livres com ou sem subvenção governamental. O que não se deveria era viver inativo, de olhos pregados num futuro que sorria ou num passado que se fora.

Todavia, para o prelado, a grande escola da instrução religiosa era o catecismo. Para isso, era fundamental a fundação de escolas primárias católicas. Por meio delas, ter-se-ia acesso à multidão de crianças. Pelo catecismo, com suas palavras fáceis e em forma de diálogo ensinar-se-iam todas as noções que o cristão deveria saber e praticar. Era o código vulgar da mais alta filosofia, alfabeto da sabedoria divina. $\mathrm{Na}$ falta de escolas primárias, o catecismo deveria ser ensinado na matriz, em outras igrejas 
ou em qualquer lugar apropriado para tal fim; ele se constituía no remédio supremo contra os males hodiernos e numa fonte de fé e virtude. Por sua vez, o catequista se assemelhava a Jesus Cristo, o maior dos catequistas. Para Dom Sebastião, esta era a principal missão do sacerdote, sua maior obrigação e mais importante encargo: instruir o povo e as crianças em hora apropriada, em todos os domingos e em dias santos. A própria Santa Sé prescreveu como gravíssima a obrigação de ensinar o catecismo.

E, se Júlio Maria concluía seu último artigo de forma, até certo ponto, apoteótica, dizendo: "Os sábios, o século, o povo nos ouvirão sem dúvida, e nós venceremos. Mas se (hipótese inverossímil) não nos ouvirem; se (por absurdo vos concedo) está decretado que os sábios não hão de querer a nossa fé, nem o século a nossa Igreja, nem o povo o nosso amor, ainda assim não podemos fugir da batalha, ainda assim não podemos nos esconder nos templos. O nosso dever é entrar na arena, travar o combate, morrer com honra"66. Dom Sebastião, menos apoteótico do que Júlio Maria e de forma objetiva, ressaltava que, se os católicos brasileiros tivessem instrução religiosa, formariam uma verdadeira e imensa maioria da nação, sobre cujos destinos haveriam de exercer benéfica e necessária influência. Instrução religiosa era a grande obra do dia. Nela, por Deus e pela Igreja, todos deveriam se empenhar.

Recebido em março de 2011. Aprovado em março de 2011. 